\title{
Insecticidal and repellent activity of the essential oil of Cinnamomum camphora var. linaloolifera Y. Fujita (Ho-Sho) and Cinnamomum camphora (L.) J Presl. var. hosyo (Hon-Sho) on Sitophilus zeamais Mots. (Coleoptera, Curculionedae)
}

\author{
CANSIAN, R.L. ${ }^{*}$; ASTOLFI, V. ${ }^{\prime ;}$ CARDOSO, R.I. ${ }^{\prime ;}$ PAROUL, N. ${ }^{\prime}$; ROMAN, S.S. ${ }^{\prime}$; MIELNICZKI-PEREIRA, \\ A.A.'; PAULETTI, G.F. ${ }^{2}$, MOSSI, A. J. ${ }^{3}$ \\ 1 Universidade Regional Integrada do Alto Uruguai e das Missões, Av. Sete de Setembro, 1621, Erechim, RS, \\ 99709-910. ' Universidade de Caxias do Sul, Rua Francisco Getulio Vargas, 1130, Caxias do Sul, RS 95070-560. \\ ${ }^{3}$ Universidade Federal Fronteira Sul, Av. Dom João Hoffmann, 313, Erechim, RS, 99700-000. *Corresponding \\ Author: cansian@uricer.edu.br
}

\begin{abstract}
The aim of this work was to evaluate the insecticidal and repellency activity of the essential oil of Cinnamomum camphora var. linaloolifera Y. Fujita (Ho-Sho) and Cinnamomum camphora (L.) J Presl.var. hosyo (Hon-Sho), against the Sitophilus zeamais in maize grains. The essential oils were obtained by hydrodistillation and analyzed by GC-MS. The insecticidal activity was determined by the toxicity of different concentrations of essential oils during 24 hours of contact with the insects, in the absence of feed substrate. The Bioassays of repellency were conducted with lethal doses $\left(\mathrm{LD}_{50}, \mathrm{LD}_{25}\right.$, and $\left.\mathrm{LD}_{12.5}\right)$ obtained from insecticidal bioassay. In order to compare the treatments the preference index $(\mathrm{PI})$ was employed. The analysis of the essential oils of Cinnamomum camphora leaves indicated $68 \%$ of camphor and $9 \%$ of linalool for the variation Hon-Sho and $95 \%$ of linalool to the variation Ho-Sho. The variation Ho-Sho presented greatest insecticidal activity than the variation Hon-Sho against the Sitophilus zeamais, with $\mathrm{LD}_{50}$ of $0.35 \mu \mathrm{L} / \mathrm{cm}^{2}$, whereas in the variation Hon-Sho the ratewas $0.48 \mu \mathrm{L} / \mathrm{cm}^{2}$. However, considering only the concentrations of linalool and camphor of Ho-Sho and Hon-Sho, the lethal doses' evaluation of these compounds were similar. The values of the preference index ranged from -0.3 to -0.8 for thevariation Ho-Sho and -0.2 to -0.7 for the variation Hon-Sho. The essential oils evaluated in this work showed repellent activity against Sitophiluszeamais in vitro and in trials performed in mini-silos.
\end{abstract}

Keywords: pest control; grains storage; maize.

RESUMO: Atividade inseticida e repelente do óleo essencial de Cinnamomum camphora var. linaloolifera Y. Fujita (Ho-Sho) e Cinnamomum camphora (L.) J Presl. var. hosyo (Hon-Sho) sobre Sitophilus zeamais Mots. (Coleoptera, Curculionedae). O objetivo deste trabalho foi avaliar a atividade inseticida e de repelência dos óleos essenciais de Cinnamomum camphora var. linaloolifera Y. Fujita (Ho-Sho) e Cinnamomum camphora (L.) J Presl. var. hosyo (Hon-Sho) contra Sitophilus zeamais em grãos de milho. Os óleos essenciais foram obtidos por hidrodestilação e analisados por CG-EM. A atividade inseticida foi determinada pela toxicidade de diferentes concentrações dos óleos essenciais durante 24 horas de contato com os insetos, na ausência de substrato alimentar. Os bioensaios de repelência foram realizados com as doses letais $\left(\mathrm{DL}_{50}, \mathrm{DL}_{25}\right.$, e $\left.\mathrm{DL}_{12.5}\right)$ obtidas do bioensaio inseticida. Para comparar os tratamentos foi utilizado o índice de preferência (PI). A análise de óleos essenciais de folhas de Cinnamomum camphora indicou a presença de $68 \%$ de cânfora e $9 \%$ de linalol na var. Hon-Sho e de $95 \%$ de linalol na var. Ho-Sho. A var. Ho-Sho apresentou maior toxicidade que var. Hon-Sho contra Sitophilus zeamais, com $\mathrm{DL}_{50}$ de $0,35 \mu \mathrm{L} / \mathrm{cm}^{2}$, enquanto que na var. Hon-Sho foi de $0,48 \mu \mathrm{L} / \mathrm{cm}^{2}$. No entanto, considerando apenas as concentrações de linalol e cânfora de Ho-Sho e Hon-Sho, a avaliação das doses letais destes compostos foram semelhantes. Os valores do índice de preferência variaram de $-0,3$ a $-0,8$ para a var. Ho-Sho e -0,2 para - 0,7 para a var. Hon-Sho. Os óleos essenciais avaliados neste trabalho apresentaram atividade repelente contra Sitophilus zeamais in vitro e em experimentos realizados em mini-silos.

Palavras-chave: controle de pragas; armazenamento de grãos; milho.

Recebido para publicação em 11/07/2014

Aceito para publicação em 02/12/2014

10.1590/1983-084X/14_074

Rev. Bras. PI. Med., Campinas, v.17, n.4, supl. I, p.769-773, 2015. 


\section{INTRODUCTION}

In order to protect agricultural crops, high amounts of synthetic pesticides are used around the world. Nowadays, the maize weevil, Sitophilus zeamais - Motsch 1855, is the most relevant pest found during storage of maize grains (Mossi et al., 2011).

Aromatic plants and their essential oils have been used since remote years in flavor and fragrances, as condiment or spice, in medicines, as antimicrobial/insecticidal agents, and to repel insect or protect stored products (Dorman \& Deans, 2000; Bakkali et al., 2008). These essential oils represent effective alternatives to synthetic pesticides without producing adverse effects on the environment (Isman, 2000; Isman \& Machial, 2006; Kordali et al., 2006). The repellence of insects with essential oils is an interesting, relatively new tool for the control of insects that mostly does not share the insecticides traditional problems have in relation to environmental and human toxicity (Isman, 2006).

Cinnamomum camphora, Lauraceae, is a Chinese medicinal plant widespread in China. The essential oils, compounds and their antimicrobial, antifungal insecticidal as well as repellent activity has been reported (Liu et al., 2001; Liu et al., 2006; Wang et al., 2005), but their effect in agricultural crops pests is not known.

In these work it was used var. Hon-Sho (Cinnamomum camphora (L.) J Presl. var. hosyo), which is high in camphor and Ho-Sho (Cinnamomum camphora var. linaloolifera Y. Fugita) which is high in linalool (Frizzo et al., 2000). These varieties are similar morphologic, however, the composition of essential oils is distinct, being considered physiologic varieties.

Essential oils from leaves of Artemisia princeps and seeds of Cinnamomum camphora displayed good repellent and insecticidal activities against storage pests Sitophillus oryzae and Bruchus rugimanus, which mixture was better (Liu et al., 2006).

Essential oils of Cinnamomum camphora, Cymbopogon winterianus, Matricaria chamomilla, Mentha viridis, Prunus amygdalus, Rosmarinus officinalis and Simmondsia chinensis were evaluated for their insecticidal and repellent properties against adults of Rhyzopertha dominica. Results indicated that adults of $R$. dominica were less susceptible to the different concentrations of tested essential oils as mortality was low $(<10 \%)$, however, C. camphora was more effective as a repellent to $R$. dominica (Al-Jabr, 2008).

In this context, the aim of this work was to evaluate the insecticidal and repellency activity of essential oil of Cinnamomum camphora var. HoSho and Hon-Sho, against the Sitophilus zeamais in maize grains.

\section{MATERIAL AND METHODS \\ Plant materials}

The essential oils of Cinnamomum camphora, var. Ho-Sho and Hon-Sho, were obtained from the Instituto de Biotecnologia da Universidade de Caxias do Sul (IB/UCS), Brazil and identified by Dr. Gabriel Pauletti. The dried leaves were hydrodistilled to extract the essential oil using a Clevengertype apparatus for $4 \mathrm{~h}$. The extraction conditions were established as $100 \mathrm{~g}$ of air-dried sample and 1:30 plant material/water volume ratio. Anhydrous sodium sulfate was used to remove the water after extraction. The extracted essential oil was stored in a refrigerator at $4{ }^{\circ} \mathrm{C}$ until analysis.

\section{Characterization of the essential oils}

The chromatographic analyses of the essential oils were performed using a Shimadzu QP 5050A series gas chromatograph (GC-MS; Osaka, Japan), using a DB-5 fused silica capillary column (30 m x $0.25 \mathrm{~mm}$ i.d. $\times 0.25 \mu \mathrm{m}$ film thickness). The temperature program used for the analysis was initial temperature at $50^{\circ} \mathrm{C}$, held for $3 \mathrm{~min}$, and ramped at $4{ }^{\circ} \mathrm{C} / \mathrm{min}$ to $300^{\circ} \mathrm{C}$. Helium was used as carrier gas at a flow rate of $1 \mathrm{~mL} / \mathrm{min}$. The detector temperature was set to $320^{\circ} \mathrm{C}$, and the injector temperature 280 ${ }^{\circ} \mathrm{C}$ with injection port (split 1:20). The identification of compounds was made by comparing the mass spectra obtained with those from the Wiley library and the retention time of analytical standards. The content of the major components of each extract is expressed as peak area percent.

\section{Insects}

Sitophilus zeamais was cultured in a controlled temperature and humidity chamber (25 $\pm 1{ }^{\circ} \mathrm{C}$ and $70-75 \%$ relative air humidity (rh) in darkness. Parent adults were obtained from the laboratory stock cultures and kept at the EMBRAPA, Passo Fundo, RS, Brazil. The food media used were whole maize grains (Prates \& Santos, 2000). The adults used in the experiment were $2-3$ weeks post-emergence.

\section{Contact toxicity on filter paper}

The contact effect of essential oils against Sitophilus zeamais was evaluated on filter paper discs (Whatman $\mathrm{N}^{\circ}{ }^{1}$ ) (14 cm diameter, surface 153.9 $\mathrm{cm}^{2}$ ), which were treated with different essential oil dosages of Ho-Sho and Hon-Sho varieties (C. camphora). The filter papers were placed in glass Petri dishes (14 cm diameter). An aliquot of $0 \mu \mathrm{L}$ (negative control), 10, 25, 50, 75, 100, 125, 150, 175 and $200 \mu \mathrm{L}$ of each essential oil was applied to the filter paper discs corresponding to dosages of $0,0.07,0.16,0.32,0.49,0.65,0.81,0.97,1.14$ and

Rev. Bras. PI. Med., Campinas, v.17, n.4, supl. I, p.769-773, 2015. 
$1.3 \mu \mathrm{L} / \mathrm{cm}^{2}$. An amount of 50 unsexed adults (3-7 days old) insect species (Sitophilus zeamais) was used separately into each dish and these were kept in darkness in the laboratory at $25 \pm 1{ }^{\circ} \mathrm{C}$ and $70-75$ $\%$ rh. The experiment was conducted in triplicate. Insect mortalities were analyzed after 24 hours. The percentage insect mortality was calculated using the Abbot correction formula for natural mortality in untreated controls (Abbot, 1925). The mortality rates were statistically evaluated by analysis of variance (ANOVA) followed by the Tukey test, using a confidence level of $95 \%$ and by regression analysis.

\section{Assessment of lethal doses and repellency bioassay}

The different $50 \%$ lethal doses $\left(L_{50}\right)$ were calculated using probit analysis (Finney, 1971). The values of $L_{50}$ calculated for each var. Ho-Sho e Hon-Sho (C. camphora), were evaluated in triplicate in the repellence bioassay.

The repellence action of the essential oils was carried out in triplicate, using a system containing five Petri plates (diameter $=14 \mathrm{~cm}$ ), codified as A, B, C, D and E. In plates A and B, 10 $g$ of maize and the essential oils were added with dose of $L_{50}$, half of $L_{50}$ and quarter $L_{50}$. In plates $\mathrm{C}$ and $\mathrm{D}$ (blanks) only the substrate was added and in plate codified as E (central), 50 adults of Sitophilus zeamais were delivered and after 24 hours the number of insects were counted. Each dish was kept in darkness at $25 \pm 1{ }^{\circ} \mathrm{C}$ and $70-75 \%$ rh. Aiming to compare the different treatments, the Preference Index $(\mathrm{PI})$ was established, as cited by Procópio et al. (2003), defined as:

\section{$\mathrm{PI}=\%$ of insects of test plants $-\%$ of insects of blank experiment \\ $\%$ of insects of test plants $+\%$ of insects of blank experiment \\ Where: \\ PI of -1.00 to -0.10 , test plant repellent; \\ $\mathrm{PI}$ of -0.10 to +0.10 , test plant neutral; \\ $\mathrm{PI}$ of +0.10 to +1.00 , test plant attractant.}

To simulate the repellent effect of essential oils in field conditions, repellency bioassays were also performed in minisilos. In this experiment, the Petry plates were replaced by silos with $6 \mathrm{~cm}$ diameter $\times 4.5 \mathrm{~cm}$ height $\left(95.4 \mathrm{~cm}^{3}\right)$ containing $50 \mathrm{~g}$ of grain in each container (proportional dimensions to real silos). The different doses $(0.12,0.25,0.37$, $0.50,0.75,1.00,1.50$ and $\left.3.00 \mu \mathrm{L} / \mathrm{cm}^{3}\right)$ were applied directly to the grain at two opposite silos. The other procedures were kept identical to the previous experiment.

\section{RESULTS AND DISCUSSION}

Chemical constituents of the essential oils

The main compounds of essential oil from Hon-Sho and Ho-Sho leaves were characterized by more than $94 \%$ of monoterpenes. Hon-Sho leaves oil were composed by $68 \%$ of camphor and $9 \%$ of linalool. The Ho-Sho leaf essential oil was almost exclusively formed by linalool (95\%), with no other constituent representing more than $1 \%$. These essential oils are similar to the most common compositions described in the literature (Fujita et al., 1974; Dung et al., 1993), where linalool content ranged 66 to $91 \%$.

\section{Filter paper contact toxicity}

The essential oil of the Cinnamomum camphora var. Ho-Sho was more efficient than var. Hon-Sho against Sitophilus zeamais (Table 1).

The significantly higher percentage of mortality $(p<0.05)$ after 24 hours of exposure, were obtained with concentrations up 0.81 and $1.14 \mu \mathrm{L} /$ $\mathrm{cm}^{2}$, respectively.

The linear regression equation of $S$. zeamais mortality was $Y=74.35 X+18,68\left(R^{2}=0.903\right)$ for Ho-Sho essential oil and $Y=78.40 X+8.523\left(R^{2}=\right.$ $0.954)$ for Hon-Sho essential oil, indicating a dosedependent response in mortality rates of $S$. zeamais.

The results obtained in this work are interesting when compared with some authors as Tapondjou et al. (2005). These authors Showed that $1.56 \mu \mathrm{L} / \mathrm{cm}^{2}$ of the essential oil of Eucaliptus saligna was necessary to obtain $100 \%$ of mortality of $S$. zeamais in the fourth day of exposure and $0.78 \mu \mathrm{L} /$ $\mathrm{cm}^{2}$ of the essential oil of Cupressus sempervirens to obtain $100 \%$ of mortality in the fifth day.

\section{Lethal doses assessment}

The probit analysis showed $\mathrm{LD}_{50}=0.35 \pm$ $0.02 \mu \mathrm{L} / \mathrm{cm}^{2}$ for Ho-Sho and $\mathrm{LD}_{50}=0.48 \pm 0.02 \mu \mathrm{L} /$ $\mathrm{cm}^{2}$ for Hon-Sho, indicating that Ho-Sho essential oil was more toxic than Hon-Sho essential oil.

However, it could be seen that, considering only the linalool and camphor concentrations, the Lethal doses assessment $\left(\mathrm{LD}_{50}\right)$ are quite similar. Ho-Sho essential oil have $\mathrm{LD}_{50}=0.35 \mu \mathrm{L} / \mathrm{cm}^{2}$ with $95 \%$ of linalool which corresponds to $0.33 \mu \mathrm{L} / \mathrm{cm}^{2}$ of linalool and the Hon-Sho have $\mathrm{LD}_{50}=0.48 \mu \mathrm{L} / \mathrm{cm}^{2}$, with $68 \%$ of camphor which corresponds to 0.326 $\mu \mathrm{L} / \mathrm{cm}^{2}$ of camphor, for lethal dose $\left(\mathrm{LD}_{50}\right)$.

\section{Repellency}

Based on the Preference Index (Table 2), the essential oils tested in this work were efficient against the adults of Sitophilus zeamais. The values of the Preference Index of essential oils ranged from -0.3 to -0.8 for var. Ho-Sho and -0.2 to -0.7 for var. Hon-Sho. According Procópio et al. (2003) an oil

Rev. Bras. PI. Med., Campinas, v.17, n.4, supl. I, p.769-773, 2015. 
TABLE 1. Percentage of mortality of Sitophilus zeamais in stored maize grains after 24 hours of exposure under different doses of essential oils of Ho-Sho and Hon-Sho.

\begin{tabular}{ccc}
\hline & \multicolumn{2}{c}{$\%$ of mortality after $24 \mathrm{~h}$ of exposure } \\
\cline { 2 - 3 } Concentration $\left(\mu \mathrm{L} / \mathrm{cm}^{2}\right)$ & Ho-Sho & Hon-Sho \\
\hline control & $0^{\circ} \pm 0$ & $0^{\mathrm{a}} \pm 0$ \\
0.07 & $20.7^{\mathrm{e}} \pm 3.1$ & $5.3^{\circ} \pm 2.5$ \\
0.16 & $42.3^{\mathrm{d}} \pm 3.2$ & $21.0^{\ddagger} \pm 4.4$ \\
0.32 & $47.3^{\mathrm{d}} \pm 4.9$ & $40.0^{\circ} \pm 4.6$ \\
0.49 & $53.0^{\circ} \pm 3.0$ & $53.3^{\mathrm{d}} \pm 4.7$ \\
0.65 & $70.0^{\mathrm{b}} \pm 2.6$ & $69.3^{\mathrm{c}} \pm 4.7$ \\
0.81 & $96.3^{\mathrm{a}} \pm 2.5$ & $80.7^{\mathrm{b}} \pm 3.2$ \\
0.97 & $96.7^{\mathrm{a}} \pm 3.0$ & $85.0^{\mathrm{b}} \pm 3.5$ \\
1.14 & $100^{\mathrm{a}} \pm 2.0$ & $96.0^{\mathrm{a}} \pm 2.6$ \\
1.30 & $100^{\mathrm{a}} \pm 1.6$ & $98.0^{\mathrm{a}} \pm 2.0$ \\
\hline
\end{tabular}

* Means followed by different letters in column are significantly different by Tukey test $(p<0.05)$.

TABLE 2. Efficiency of the treatments of repellency activity with different doses of essential oil of Cinnamomum camphora Nees \& Eberm, var. Ho-Sho and Hon-Sho against Sitophilus zeamais in stored maize grains.

\begin{tabular}{ccccc}
\hline \multirow{2}{*}{ Concentration } & \multicolumn{3}{c}{ Ho-Sho } & \multicolumn{2}{c}{ Hon-Sho } \\
\cline { 2 - 5 } & $\left(\mu \mathrm{L} / \mathrm{cm}^{2}\right)$ & $\mathrm{Pl}^{*}$ & $\left(\mu \mathrm{L} / \mathrm{cm}^{2}\right)$ & $\mathrm{Pl}$ \\
\hline $\mathrm{LD}_{50}$ & 0.35 & -0.8 & 0.48 & -0.7 \\
$\mathrm{LD}_{25}$ & 0.18 & -0.5 & 0.24 & -0.5 \\
$\mathrm{LD}_{12.5}$ & 0.09 & -0.3 & 0.12 & -0.2 \\
\hline
\end{tabular}

${ }^{*}$ Preference Index (PI)

should have preference index lower than -0.10 to consider repellency activity.

Procópio et al. (2003) evaluated the repellency effect of fragments of leaves of six vegetables species against adults of Sitophilus zeamais and verified, based on the PI, that two species caused repellency, the leaves of Eucalyptus citriodora (Myrtaceae) $(\mathrm{PI}=-0.81)$ and Capsicum frutescens (Solanaceae) $(\mathrm{PI}=-0,17)$.

The highly toxic and repellent effects of main constituents of these oils, camphor and linalool, have been demonstrated by other researchers (Chen et al., 2013; Ajayi et al., 2014). Linalool was shown to exhibit fumigant toxicity against $S$. zeamais (Wang et al. 2011; Liu et al., 2013; Yildirim et al., 2013) and the C. camphora, with camphor as major component, showed repellent activity (Liu et al., 2006) and high insecticidal activity against $S$. oryzae (Hamed et al., 2012).

When assessing the repellency performed in silos, was observed effect at doses above 0.75 and $1.00 \mu \mathrm{L} / \mathrm{cm}^{3}$ for Ho-Sho and Hon-Sho, respectively (Table 3).

The lower doses were shown to be neutral but not attractive. Extrapolating the results, would be needed a minimum of 1.43 and $1.91 \mathrm{~L} /$ ton of Ho-Sho and Hon-Sho essential oil, respectively for repelling Sitophilus zeamais in field conditions.

TABLE 3. Efficiency of the treatments of repellency activity with different doses of essential oil of Cinnamomum camphora Nees \& Eberm, var. Ho-Sho and Hon-Sho against Sitophilus zeamais in maize storage silo.

\begin{tabular}{ccc}
\hline \multirow{2}{*}{ Concentration $\left(\mu \mathrm{L} / \mathrm{cm}^{3}\right)$} & Ho-Sho & Hon-Sho \\
\cline { 2 - 3 } & $\mathrm{Pl}^{*}$ & $\mathrm{Pl}$ \\
\hline 0 (control) & 0.5 & 0.7 \\
0.12 & 0.4 & 0.3 \\
0.25 & 0.1 & 0.2 \\
0.37 & 0.1 & 0.1 \\
0.50 & -0.1 & 0.2 \\
0.75 & -0.3 & -0.1 \\
1.00 & -0.5 & -0.3 \\
1.50 & -0.7 & -0.5 \\
3.00 & -0.7 & -0.5 \\
\hline
\end{tabular}

${ }^{*}$ Preference Index (PI)

The comparison between the composition of the different essential oils evaluated in this work, 
showed that both Ho-Sho, rich in linalool, as HonSho, rich in camphor, have insecticidal and repellent activity against Sitophilus zeamais.

\section{ACKNOWLEDGMENTS}

The authors thanks the CNPq, FAPERGS and SCIT-RS by the financial support.

\section{REFERENCES}

ABBOT, W.S. A method for computing the effectiveness of an insecticide. Journal of Economic Entomology, v. 18, p. 265-267, 1925.

AJAYI, O.E. et al. Fumigation Toxicity of Essential Oil Monoterpenes to Callosobruchus maculatus (Coleoptera: Chrysomelidae: Bruchinae). Journal of Insects, v. 2014, p. 1-7, 2014.

AL-JABR, A.M. Toxicity, repellency and bioactivity of seven plant oils to storage pest Rhyzopertha dominica (F.) (Coleoptera: Bostrichidae) on wheat. Journal of Food Science and Technology, v. 45, n. 6, p. 520-523, 2008.

BAKKALI, F. et al. Biological effects of essential oils - a review. Food and Chemical Toxicology, v. 46, n. 2, p. 446-475, 2008.

CHEN, W. et al. Camphor - A Fumigant during the Black Death and a Coveted Fragrant Wood in Ancient Egypt and Babylon - A Review. Molecules, v. 18, p. 54345454, 2013.

DORMAN, H.J.D.; DEANS, S.G. Antimicrobial agents from plants: antibacterial activity of plant volatile oils. Journal of Applied Microbiology, v. 88, p. 308-316, 2000.

DUNG, N.X. et al. The essential oil of Cinnamomum camphora (L.) Sieb. var. linaloolifera from Vietnam. Journal of Essential Oil Research, v. 5, p. 451-453, 1993.

FINNEY, D. J. Probit Analysis. 3. ed. Cambrige: Cambridge University Press, 1971. 333p.

FRIZZO, C.D. et al. Essential Oils of Camphor Tree (Cinnamomum camphora Nees \& Eberm) Cultivated in Southern Brazil. Brazilian Archives of Biology and Technology, v. 43, n.3, p. 313-316, 2000.

FUJITA, Y. et al. Biogenesis of the essential oils in camphor trees. XXXI. Components of young and old shoot oils of Cinnamomum camphora var. linaloolifera. Osaka Kogyo Gijutsu Shikensho Kiho v. 25, p. 244-246, 1974.

HAMED, R.K.A. et al. Efficacy of certain plant oils as grain protectants against the rice weevil, Sitophilus oryzae (Coleoptera: Curculionidae) on wheat. Egyptian Academic Journal of Biological Science, v. 5, n. 2, p. 49-53, 2012.

ISMAN, M.B. Plant essential oils for pest and disease management. Crop protection, v. 19, p. 603-608, 2000.

ISMAN, M.B. Botanical insecticides, deterrents, and repellents in modern agriculture and an increasingly regulated world. Annual Review of Entomology, v. 51, p. 45-66, 2006.

ISMAN, M.B.; MACHIAL, C.M. Pesticides based on plant essential oils: from traditional practice to commercialization. In: RAI, M.; CARPINELLA, M.C. Naturally Occurring Bioactive Compounds. Amsterdam: Elsevier, 2006, p.29-44.

KORDALI, S. et al.Toxicity of essential oils isolated from three Artemisia species and some of their major components to granary weevil, Sitophilus granarius (L.) (Coleoptera: Curculionidae). Industrial Crops and Products, v. 23, p. 162-170, 2006.

LIU, C.H. et al. Repellent and insecticidal activities of essential oils from Artemisia princeps and Cinnamomum camphora and their effect on seed germination of wheat and broad bean. Bioresource Technology, v. 97, p. 1969-1973, 2006.

LIU, H. et al. Composition and antifungal activity of essential oils from Artemisia princeps and Cinnamomum camphora. International Pest Control, v. 47, p. 72-74, 2001.

LIU, X.C. et al. Identification of repellent and insecticidal constituents of the essential oil of Artemisia rupestris L. aerial parts against Liposcelis bostrychophila Badonnel. Molecules, v. 18, p. 10733-10746, 2013.

MOSSI, A.J. et al. Insecticidal and repellency activity of essential oil of Eucalyptus sp. against Sitophilus zeamais Motschulsky (Coleoptera, Curculionidae). Journal of the Science of Food and Agriculture, v.91, p. 273-277, 2011.

PRATES, H.T.; SANTOS, J.P. Óleos essenciais no controle de pragas de grãos armazenados. In: LORINI, I.; MIIKE, L.H.; SCUSSEL, V.M. Armazenagem de Grãos. Campinas: IBG, 2000, p.443-461.

PROCÓPIO, S.O. et al. Bioatividade de diversos pós de origem vegetal em relação à Sitophilus zeamais Mots. (Coleoptera: Curculionidae). Ciência e Agrotecnologia, v. 27, p. 1231-1236, 2003.

TAPONDJOU, A.L. et al. Bioactivities of cymol and essential oils of Cupressus sempervirens and Eucalyptus saligna against Sitophilus zeamais Motschulsky and Tribolium confusum du Val. Journal of Stored Products Research, v. 41, p. 91-102, 2005.

WANG, S.Y. et al. Antifungal activities of essential oils and their constituents from indigenous cinnamon (Cinnamomum osmophloeum) leaves against wood decay fungi. Bioresource Technology, v. 96, n. 7, p. 813-818, 2005.

WANG, C.F. et al. Components and insecticidal activity against the maize weevils of Zanthoxylum schinifolium fruits and leaves. Molecules, v. 16, p. 3077-3088, 2011.

YILDIRIM, E. et al. Insecticidal effects of monoterpenes on Sitophilus zeamais Motschulsky (Coleoptera: Curculionidae). Journal of Applied Botany and Food Quality, v. 86, p. 198-204, 2013. 